\title{
Rebound hyperkalemia after cessation of ritodrine in a parturient undergoing cesarean section
}

\author{
Daiki Takekawa ${ }^{1 *}$, Kei Jinushi ${ }^{1}$, Masato Kitayama ${ }^{2}$ and Kazuyoshi Hirota ${ }^{1}$
}

\begin{abstract}
A 36-year-old parturient with a suspicion of placenta accreta under tocolytic therapy with ritodrine infusion underwent emergency cesarean section under general anesthesia with propofol, ketamine, and remifentanil because massive bleeding was anticipated. The ritodrine infusion was discontinued $1 \mathrm{~h}$ before cesarean section. The baby was delivered 6 min after induction of anesthesia. However, after the manual removal of the placenta from the uterus, the bleeding was massive and uncontrollable. We rapidly transfused crystalloid, colloid, and red blood cells through potassium removal filter. Hyperkalemia $(5.8 \mathrm{mmol} / \mathrm{L})$ was detected just before blood transfusion. One hour later, hemostasis was still difficult, and hyperkalemia was promoted (6.1 mmol/L). Thus, glucose insulin therapy started with intravenous furosemide to treat hyperkalemia. Gynecologists decided to induce the Bakri balloon tamponade for the treatment of postpartum hemorrhage. At the end of surgery, plasma potassium level also reduced to $5.5 \mathrm{mmol} / \mathrm{L}$. In the ICU, the bleeding still continued, and then radiologists performed bilateral internal iliac artery embolization for full hemostasis. Postoperative plasma potassium level was stable and $3.3 \mathrm{mmol} / \mathrm{L}$ in the next morning. Although one of the common adverse reactions of ritodrine is hypokalemia, we should also beware of a rebound hyperkalemia after its cessation.
\end{abstract}

Keyword: Ritodrine, Cesarean section, Hyperkalemia

\section{Background}

Ritodrine, a $\beta_{2}$-adrenergic agonist, is widely used for tocolytic therapy in parturients. However, one of the common adverse effects of $\beta_{2}$-agonists is hypokalemia (relative risk, 6.07; 95\% confidence interval, 4.00 to 9.20) [1], which is due to an increase in uptake of extracellular potassium by promoting insulin secretion in pancreatic islets with $\beta_{2}$ adrenoceptor stimulation [2]. However, we experienced a case revealing a rebound hyperkalemia after cessation of ritodrine. This adverse reaction may rarely occur as only five case reports have been found by PubMed search [3-7].

\section{Case presentation}

We have obtained a written informed consent for publication of this case report from the patient.

\footnotetext{
*Correspondence: takekawa.daiki50@gmail.com

'Department of Anesthesiology, Hirosaki University Graduate School of

Medicine, 5 Zaifu-cho, Hirosaki 036-8562, Japan

Full list of author information is available at the end of the article
}

A 36-year-old parturient $(170 \mathrm{~cm}, 74.8 \mathrm{~kg}$, gravida 1 , para 1) with a suspicion of placenta accreta at 34 weeks gestation was admitted into our university hospital. She did not have any abnormal medical history. On the 3rd day after admission, tocolytic therapy against frequent uterine contractions started with intravenous infusion of ritodrine at $50 \mu \mathrm{g} / \mathrm{min}$. On the 5 th day, its infusion dose reduced to $35 \mu \mathrm{g} / \mathrm{min}$ because of her palpitation with tachycardia (HR $120 \mathrm{bpm}$ ). On the 6th day, the serum potassium level was $4.1 \mathrm{mmol} / \mathrm{L}$. On the 7 th day, as spontaneous amniorrhexis occurred, emergency cesarean section was scheduled, and the ritodrine infusion was discontinued ( $1 \mathrm{~h}$ before cesarean section).

We chose general anesthesia for the emergency cesarean section as massive bleeding due to placenta accreta was anticipated. Anesthesia was induced with intravenous propofol $(150 \mathrm{mg})$ and suxamethonium (50 mg) followed by tracheal intubation uncomplicatedly, and then maintained with propofol $(6 \mathrm{mg} / \mathrm{kg} / \mathrm{h})$ till delivery. The baby was delivered $6 \mathrm{~min}$ after 
induction of anesthesia. Then, fentanyl and ketamine were additionally given to deepen anesthesia. Rocuronium was also given to maintain muscle relaxation. After the manual removal of the placenta from the uterus, the bleeding was massive and uncontrollable $(2200 \mathrm{~g}$ in about $20 \mathrm{~min}$ ). We rapidly transfused colloidal solution against hypotension $(63 / 35 \mathrm{mmHg})$, and blood pressure increased to $90 / 50 \mathrm{mmHg}$ within $10 \mathrm{~min}$. We also established an arterial line to left radial artery to maintain blood pressure. Arterial blood gas analyses revealed hyperkalemia $(5.8 \mathrm{mmol} / \mathrm{L})$, anemia $(\mathrm{Hb} 5.0 \mathrm{~g} / \mathrm{dL})$, and mild metabolic acidosis $(\mathrm{pH}$ 7.33, base excess (BE) $-4.5 \mathrm{mEq} / \mathrm{L}$, lactate $1.7 \mathrm{mmol} / \mathrm{L})$. We started blood transfusion with potassium removal filter (potassium adsorption filter (KPF-4), Kawasumi, Tokyo). One hour later, hemostasis was still difficult, and the biochemical date showed further hyperkalemia $(6.1 \mathrm{mmol} / \mathrm{L})$ without any electrocardiographic changes and development of metabolic acidosis $(\mathrm{pH} 7.33, \mathrm{BE}-5.2 \mathrm{mEq} / \mathrm{L}$, lactate $1.0 \mathrm{mmol} / \mathrm{L}$ ). To treat hyperkalemia, glucose insulin therapy started with intravenous furosemide $(10 \mathrm{mg})$. Because of insufficient hemostasis, gynecologists decided to induce the Bakri balloon tamponade for the treatment of postpartum hemorrhage. At the induction of the Bakri balloon, the hematological data were improved $(\mathrm{Hb}$ $6.1 \mathrm{~g} / \mathrm{dL}$ ). In addition, plasma potassium level also reduced to $5.5 \mathrm{mmol} / \mathrm{L}$. Thus, the operation was terminated $(1 \mathrm{~h} 54 \mathrm{~min})$ with a total blood loss of $4000 \mathrm{~g}$ and urine output of $400 \mathrm{~mL}$. Crystalloid $(800 \mathrm{~mL})$, colloid (HES 130/0.4) (1500 mL), 5\% albumin $(500 \mathrm{~mL})$, and packed red blood cell ( 6 units) were totally transfused during operation. She postoperatively moved to the intensive care unit under propofol sedation with tracheal intubation. The trachea was extubated after confirming stable hemodynamics and oxygenation. However, as the bleeding still continued, radiologists finally performed bilateral internal iliac artery embolization for full hemostasis. The postoperative course was uneventful and plasma potassium level was $3.3 \mathrm{mmol} / \mathrm{L}$ in the next morning. She was discharged from the hospital on foot without any sequelas on the 13th postoperative day.

\section{Discussion}

Ritodrine is a $\beta_{2}$-mimetic and commonly used for management of preterm labor. The common side effect of ritodrine is hypokalemia as $\beta_{2}$-adrenoceptor stimulation in pancreatic islets by ritodrine promotes insulin secretion to increase uptake of extracellular potassium [2]. However, in the present case, hyperkalemia occurred $1 \mathrm{~h}$ after cessation of ritodrine. Vanishing $\beta_{2}$-stimulation following cessation of ritodrine conversely increases efflux of potassium from the cells to increase plasma potassium levels. Indeed, there are several similar case reports revealing hyperkalemia following cessation of ritodrine in parturients [3-7]. In addition, in the present case, surgical stress with massive bleeding could reduce insulin secretion and induce insulin resistance by increases in catecholamine and cortisol release. As a result, efflux of potassium from the cell was promoted to enhance hyperkalemia.

In the present case, hyperkalemia became rapidly apparent even $1 \mathrm{~h}$ after cessation of ritodrine infusion. It has been reported that plasma ritodrine concentration rapidly declines following termination of its infusion with a distribution half-time of $5.9 \pm 6.0 \mathrm{~min}$ and a disposition half-time of $156 \pm 51 \mathrm{~min}$ [8]. Thus, we have to monitor plasma potassium levels around $3 \mathrm{~h}$ after cessation of ritodrine. Indeed, Kotani and colleagues [5] reported that maximal hyperkalemia was observed 90 $150 \mathrm{~min}$ after its cessation in six patients.

Unexpected hyperkalemia following intravenous suxamethonium has also been reported in parturients treated with magnesium and ritodrine under prolonged immobilization [6]. As suxamethonium was used to facilitate tracheal intubation in the present case, it might reinforce ritodrine-induced rebound hyperkalemia. Although plasma potassium levels may increase up to $1.0 \mathrm{mmol} / \mathrm{L}$ within $2-5 \mathrm{~min}$ following intravenous suxamethonium and the level quickly returns to a baseline value in healthy persons [9], hyperkalemia was detected even $1 \mathrm{~h}$ after iv suxamethonium. Therefore, iv suxamethonium may not be the main cause of hyperkalemia in the present case.

The following causes of perioperative hyperkalemia should also be considered: rhabdomyolysis from malpositioning, tissue ischemia, metabolic and respiratory acidosis, and blood transfusion [9]. In the present case, as positioning was carefully done to avoid peripheral nerve injury, rhabdomyolysis could be excluded from the cause. Although the lowest blood pressure was 63/ $35 \mathrm{mmHg}$, blood pressure increased to $90 / 50 \mathrm{mmHg}$ by rapid blood and colloid transfusion. In addition, intraoperative plasma lactate level was also within normal $(<2 \mathrm{mmol} / \mathrm{L})$ during surgery. Thus, tissue ischemia could also be excluded. As arterial blood gas analysis revealed mild metabolic acidosis (BE, -4.5 and $-5.2 \mathrm{mEq} / \mathrm{L}$ ), it might cause an increase in plasma potassium level. However, a parturient generally show low arterial $\mathrm{CO}_{2}$ with a parallel reduction in plasma $\mathrm{HCO}_{3}^{-}$because of hyperventilation induced by effects of progesterone on the respiratory center [10]. Particularly in labor, $\mathrm{BE}$ and $\mathrm{HCO}_{3}^{-}$decrease to -4.8 and $20.3 \mathrm{mEq} / \mathrm{L}$ [10]. Therefore, slight low BE in the present case would be acceptable and would not cause hyperkalemia.

\section{Conclusions}

In summary, we experienced a case of rebound hyperkalemia after cessation of ritodrine in a parturient 
undergoing an emergency cesarean section with massive bleeding. We should pay attention to perioperative hyperkalemia in a parturient treated with ritodrine for tocolytic therapy.

\section{Authors' contributions}

DT collected the data and drafted the manuscript. KJ, MK, and $\mathrm{KH}$ revised the manuscript. All authors read and approved the final manuscript for submission.

\section{Competing interests}

The authors declare that they have no competing interests.

\section{Author details}

${ }^{1}$ Department of Anesthesiology, Hirosaki University Graduate School of Medicine, 5 Zaifu-cho, Hirosaki 036-8562, Japan. Division of Operating

Theater, Hirosaki University Hospital, 53 Hon-cho, Hirosaki 036-8563, Japan.

Received: 12 October 2016 Accepted: 13 December 2016

Published online: 05 January 2017

\section{References}

1. Neilson JP, West HM, Dowswell T. Betamimetics for inhibiting preterm labour. Cochrane Database Syst Rev. 2014;2:CD004352.

2. Lenard NR, Dunn AJ. Increased insulin is not required for $\beta_{2}$-adrenoceptorinduced increases in mouse brain tryptophan. Eur J Pharmacol. 2004;497: 105-10.

3. Braden GL, vonOeyen PT, Germain MJ, Watson DJ, Haag BL. Ritodrine- and terbutaline-induced hypokalemia in preterm labor: mechanisms and consequences. Kidney Int. 1997;57:1867-75.

4. Kuczkowski KM, Benumof JL. Rebound hyperkalemia after cessation of intravenous tocolytic therapy with terbutaline in the treatment of preterm labor: anesthetic implications. J Clin Anesth. 2003:15:357-8.

5. Kotani N, Kushikata T, Hashimoto H, Muraoka M, Tonosaki N, Matsuki A. Rebound perioperative hyperkalemia in six patients after cessation of ritodrine for premature labor. Anesth Analg. 2001;93:709-11.

6. Sato K, Nishiwaki K, Kuno N, Kumagai K, Kitamura H, Yano K, et al. Unexpected hyperkalemia following succinylcholine administration in prolonged immobilized parturients treated with magnesium and ritodrine. Anesthesiology. 2000;93:1539-41.

7. Kinoshita H, Katoh Y, Yoshino H, Sumie Y, Tanaka M, Fujiwara Y. Acute hypokalemia induced by ritodrine and rebound hyperkalemia in a parturient undergoing a cesarean section. J Clin Anesth. 2016;28:78-9.

8. Caritis SN, Venkataramanan R, Darby MJ, Chiao JP, Krew M. Pharmacokinetics of ritodrine administered intravenously: recommendations for changes in the current regimen. Am J Obstet Gynecol. 1990;162:429-37.

9. Ayach T, Nappo RW, Paugh-Miller JL, Ross EA. Postoperative hyperkalemia. Eur J Intern Med. 2015:26:106-11.

10. Omo-Aghoja L. Maternal and fetal acid-base chemistry: a major determinant of perinatal outcome. Ann Med Health Sci Res. 2014:4:8-17.

\section{Submit your manuscript to a SpringerOpen ${ }^{\circ}$ journal and benefit from:}

- Convenient online submission

- Rigorous peer review

- Immediate publication on acceptance

- Open access: articles freely available online

- High visibility within the field

- Retaining the copyright to your article 